\title{
GEOLOGY OF THE SHINARUMP NO. 1 \\ URANIUM MINE, SEVEN MILE CANYON AREA, GRAND COUNTY, UTAH
}

This report concerns work done on behalf of the U.S. Atomic Energy Commission and is published with the permission of the Commission. 
UNITED STATES DEPARTMENT OF THE INTERIOR

Douglas McKay, Secretary

GEOLOGICAL SURVEY

W. E. Wrather, Director

GEOLOGICAL SURVEY CIRCULAR 336

GEOLOGY OF THE SHINARUMP NO. 1 URANIUM MINE, SEVEN MILE

CANYON AREA, GRAND COUNTY, UTAH

By W. I. Finch

This report concerns work done on

behalf of the U. S. Atomic Energy

Commission and is published with

the permission of the Commission. 


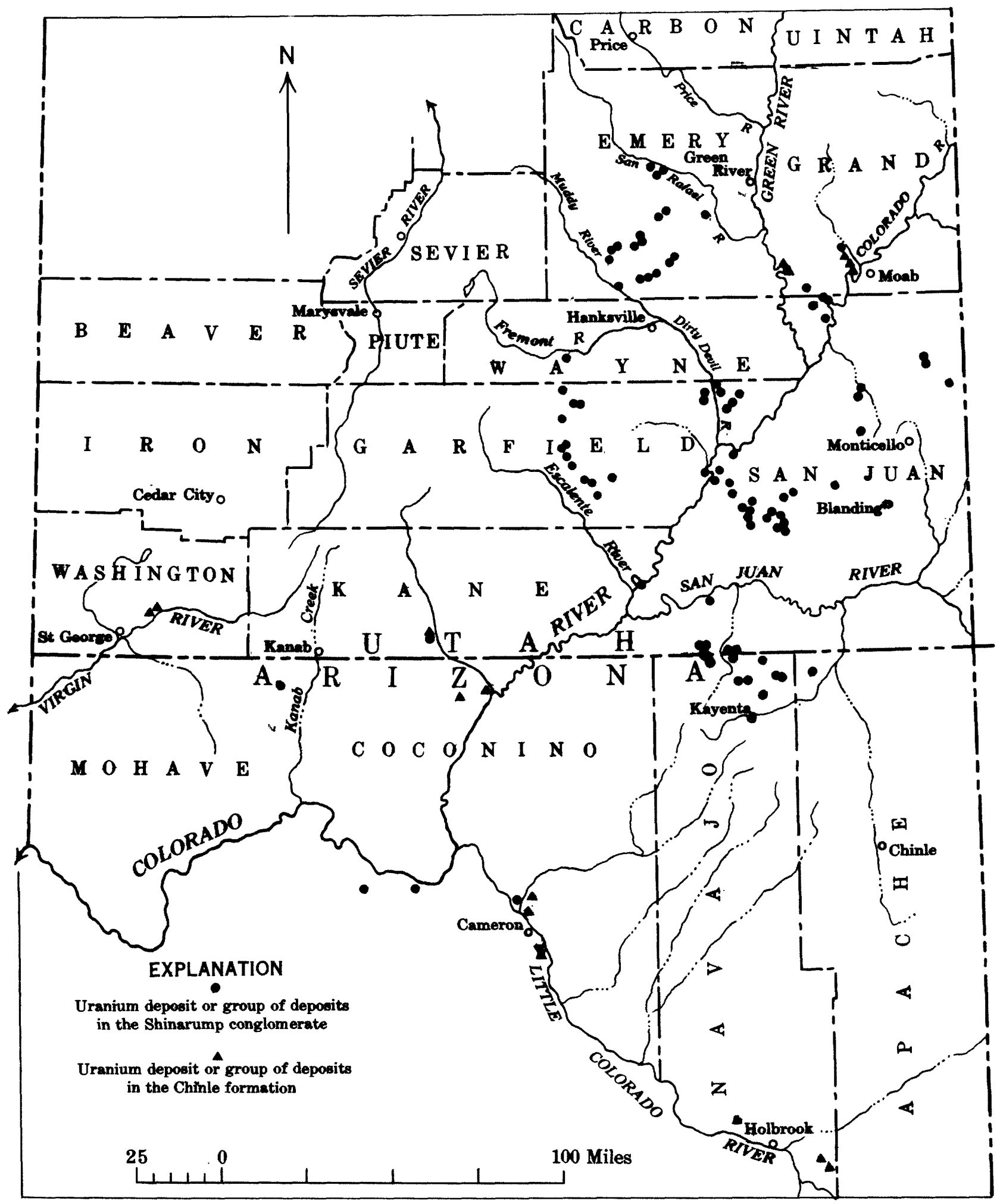

Figure 1. - Map of part of the Colorado Plateau showing the location of the Shinarump No. 1 mine and the distribution of uranium deposits in the Shinarump and Chinle formations. 


\title{
GEOLOGY OF THE SHINARUMP NO. 1 URANIUM MINE, SEVEN MILE CANYON AREA, GRAND COUNTY, UTAH
}

\author{
By W. I. Finch
}

CONTENTS

\begin{tabular}{|c|c|c|}
\hline & lage & Page \\
\hline Abstract. ......... & 1 & 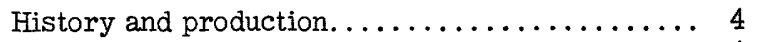 \\
\hline 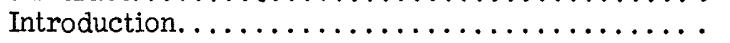 & 2 & 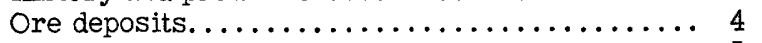 \\
\hline 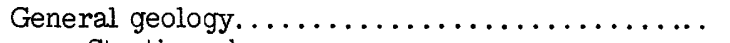 & 2 & 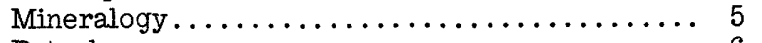 \\
\hline 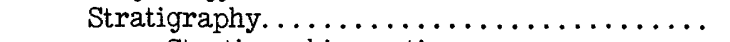 & 2 & 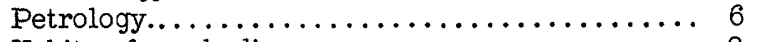 \\
\hline Stratigraphic section $\ldots \ldots \ldots \ldots \ldots$ & 2 & Habits of ore bodies $\ldots \ldots \ldots \ldots \ldots \ldots \ldots$ \\
\hline Cutler formation. ............. & 3 & Spectrographic study.................. 10 \\
\hline Moenkopi formation $\ldots \ldots \ldots \ldots \ldots \ldots$ & 3 & Age determinations of uraninite. .......... 12 \\
\hline Shinarump conglomerate & & Origin of deposit................... 12 \\
\hline and Chinle formation . .......... & 3 & Conclusions..................... 13 \\
\hline Wingate sandstone............... & 4 & Literature cited................... 13 \\
\hline Jurassic rocks............... & 4 & Unpublished reports . . . . . . . . . . . . 14 \\
\hline Structure................... & 4 & Group number classification. . . . . . . . . . 14 \\
\hline
\end{tabular}

\section{ILLUSTRATIONS}

[Plates are in pocket]

Plate 1. Geologic maps and sections of the Seven Mile Canyon and Shinarump No. 1 mine areas, Grand County, Utah.

2. Selected maps of mine walls from the Shinarump No. 1 mine.

Figure 1. Map of part of the Colorado Plateau showing the location of the Shinarump No. 1 mine and the distribution of uranium deposits in the Shinarump and Chinle formations. . ......... ii

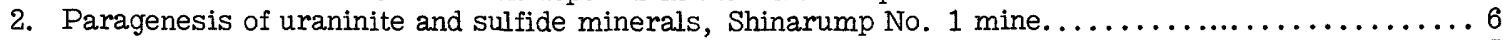

3. Photomicrographs of polished and thin sections from the Shinarump No. 1 mine $\ldots \ldots \ldots \ldots \ldots \ldots \ldots \ldots$

4. Cumulative curves of grain size of samples from the Seven Mile Canyon area. . . . . . . . . . . . . 9

5. Frequency curves of grain size of samples from the Seven Mile Canyon area . . . . . . . . . . . . 9

6. Curves of grain size of ore-bearing and barren siltstone from Shinarump No. 1 mine......... 10

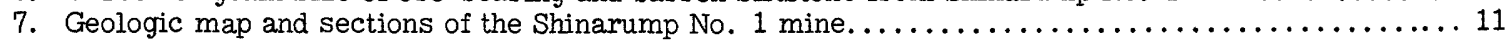

TABLES

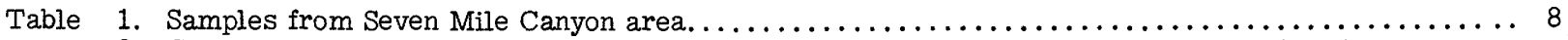

2. Geometric mean values (in percent) of elements contained in barren and uranium-bearing rock from the Shinarump No. 1 mine, copper-bearing rock from nearby copper deposits, and uranium-bearing rock from a nearby deposit in the Morrison formation ..............

\section{ABSTRACT}

The geology of the Shinarump No. 1 uranium mine, located about 12 miles northwest of Moab, Utah, in the Seven Mile Canyon area, Grand County, Utah, was studied to determine the habits, ore controls, and possible origin of the deposit.

Rocks of Permian, Triassic, and Jurassic age crop out in the area mapped, and uranium deposits are found in three zones in the lower 25 feet of the Chinle formation of Late Triassic age. The Shinarump No. 1 mine, which is in the lowermost zone, is located on the west flank of the Moab anticline near the Moab fault.

The Shinarump No. 1 uranium deposit consists of discontinuous lenticular layers of mineralized rock, irregular in outline, that, in general, follow the bedding. Ore minerals, mainly uraninite, impregnate the rock. High-grade ore seams of uraninite and chalcocite occur 
along bedding planes. Uraninite formed later than, or simultaneous with, most sulfides, and the chalcocite may be of two ages, with some being later than uraninite. Uraninite and chalcocite are concentrated in the more poorly sorted parts of siltstones. In the Seven Mile Canyon area guides to ore inferred from the study of the Shinarump No. 1 deposit are the presence of bleached siltstone, carbonaceous matter, and copper sulfides. Results of spectrographic analysis indicate that the mineralizing solutions contained important amounts of barium, vanadium, uranium, and copper, as well as lesser amounts of strontium, chromium, boron, yttrium, lead, and zinc.

The origin of the Shinarump No. 1 deposit is thought to be hydrothermal.

\section{INTRODUCTION}

The Shinarump No. 1 uranium mine is located about 12 miles northwest of Moab, Utah, in the Seven Mile Canyon area, Grand County, Utah (fig. 1). A road about a quarter of a mile long connects the mine area with U. S. Highway 160 . The mineralized zones crop out along a northwest-trending escarpment paralleling Highway 160. Vegetation in the area is sparse.

The United States Geological Survey studied the geology of the Shinarump No. 1 mine on behalf of the Atomic Energy Commission in order to determine the habits, ore controls, and possible origin of the deposit. Vance Thornburg, owner of the claims, was most cooperative and helpful throughout the investigation.

Field study began in January 1952 and was carried on intermittently until April 1953. The Shinarump No. 1 mine workings were mapped in detail by tape and opensight alidade early in 1952. Later a planetable map was made of the area surrounding the mine to relate the mine geology to the stratigraphic and structural features. A total of 31 samples of ore-bearing and barren rock were taken in the area and analyzed chemically and spectrographically. Stratigraphic sections were measured near the mine and in Little Canyon south of Seven Mile Canyon.

Previous work in the area includes a study of the geology of the area between the Green and Colorado Rivers by McKnight (1940) and recent studies of the Seven Mile Canyon area in connection with exploration by the Atomic Energy Commission by Droullard (1951) and Droullard and Jones (1952).

\section{GENERAL GEOLOGY}

Rocks of Permian, Triassic, and Jurassic age crop out in the area mapped. Uranium-bearing rock occurs in lower beds of the Upper Triassic rocks. Copper-bearing rock occurs in a large talus block that may be Dakota sandstone of Cretaceous age and in the Moab fault gouge zone. Outside the Shinarump No. 1 mine area, uraniumbearing rock also occurs in the Morrison formation of Late Jurassic age (pl. 1). Copper-bearing rock occurs along the Moab fault northwest of the area mapped.

The nearest igneous rocks crop out in the La Sal Mountain laccolith about 20 miles to the southeast. The major structural features are the Moab anticline and Moab fault. The general geology of the surrounding area is given by McKnight (1940). Below is a brief discussion of the stratigraphy and structure of the Shinarump No. 1 mine area.

\section{Stratigraphy}

\section{Stratigraphic section}

In the Shinarump No. 1 mine area, the Cutler, Moenkopi, Shinarump, Chinle, and Wingate formations form an escarpment along the west side of the Moab fault. The Upper Jurassic Morrison formation on the east side of the fault has been faulted against the Permian Cutler formation. Thus, in the area mapped, Jurassic rocks between the Wingate (Triassic) and Morrison formations are not exposed. A measured section of the rocks near the mine follows.

Shinarump no. 1 claim section, measured about 1,500 feet south of Corral Canyon, Grand County, Utah. Line of section S. 65 W., sec. 27, T. 24 S. R. 20 E., Salt Lake meridian

[Measured December 1952]

Wingate sandstone (incomplete)

Top of section, not top of exposure.

Sandstone, yellowish-gray $(5 \mathrm{Y} 8 / 1)^{i}$ weathers pale red (1OR6/2); fine-grained to very fine grained; bedding not distinct; only basal $5 \mathrm{ft}$ examined; estimated height of cliff face $220 \mathrm{ft}$. Chinle formation and Wingate sandstone contact placed at sharp change from cliff-forming sandstone of Wingate to slope-forming shale and sandstone of Chinle. Mudcracks at base of Wingate; light-green alteration of upper few inches of Chinle and of mudcrack fillings. (Unit not measured.)

Unconformity (local?).

\section{Chinle formation:}

Shale and interbedded sandstone and conglomerate, pale-red (1OR6/2); sandstone, fine-grained; conglomerate contains mostly clastic limestone concretions. Sandstone and conglomerate beds mostly $1 \mathrm{ft}$ or less in thickness. For most part unit forms steep rubble-covered slope..............73

Sandstone, light-red ( $5 \underline{R} 6 / 6)$, fine-grained; quartzitic; thin horizontal bedding with some low-angle crossbedding; forms ledge; channels into lower unit. .................

Sandstone and mudstone, moderate-red (5R5/4), fine-grained; irregular bedding; forms ledge ..................... 12

Sandstone and conglomerate, pale-red (5R6/2) and light greenish-gray (5GY8/1), fine-grained. Conglomerate consists mainly of clastic limestone concretions. Abundant hematitic concretions scattered mainly in sandstone beds, some silicified wood, some white calcite filling cavities and fractures. Irregular bedding and penecontemporaneous slumping. This and upper two beds form a single ledge which divides the Chinle into two units; base of unit channels in lower beds and is base of upper

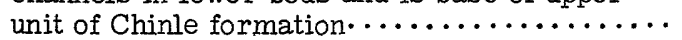

Feet

${ }^{1}$ See footnote p. 3. 
Chinle formation-Continued

Sandstone, pale-red (5R6/2) fine-grained,

thin-bedded; with interbeds of yellowish gray (5Y7/2); beds weather with hackly surface; forms a steep covered slope ...

Conglomerate, yellowish-gray ( $5 \underline{Y} 7 / 2)$;

clastic limestone concretions and

some white quartz; pebbles range

from $\frac{1}{4}$ to 2 inches across; calcareous

cement; irregular bedding; forms ledge..... 6

Sandstone and siltstone, moderate

red-orange (10R6/6); sandstone, fine-

grained, in beds mainly $1 \mathrm{ft}$ thick

which form discontinuous channel-

fillings; small scale crossbedding;

some miniature slumping; unit forms slope... 48

Sandstone, grayish-green (5GY6/1),

fine-grained; composed of quartz grains,

white mica, some carbon flecks; cal-

careous cement; thin-bedded; weathers

into small irregular crescent-shaped

partings; forms slope; lenticular,

channels into lower unit ...............

Siltstone, dark red-brown (10R3/4);

some white mica and coarse quartz

sand grains; thin-bedded; forms slope;

uranium bearing in places............. 22

Claystone and siltstone, light-green

(5G7/4) and light-brown (5YR6/4); some

fine quartz grains, white and green

mica, wood fragments; thin-bedded;

forms slope; grades into overlying

beds. Uranium bearing in places;

some wood replaced by uraninite

and becquerelite

Conglomerate, greenish-gray ( $5 \underline{G} \underline{\underline{Y}} 6 / 1)$;

clastic lime pebbles as much as 2 in.

across, some quartz grains, some

limonitic stains; calcareous cement;

uneven bedding; forms ledge. Uranium

bearing in upper part, uraninite forms

rims about some limestone pebbles......... 13

Mudstone, pale-red (10R6/2); some lime-

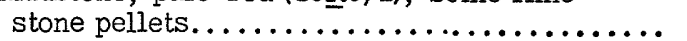

Conglomerate, pale-green (5G7/2);

clastic limestone pebbles; calcareous

cement; irregular bedding ..............

Siltstone and conglomerate, moderate

reddish-orange (10R6/6); conglomerate

contains clastic limestone pebbles

and reworked siltstone pebbles from

the Moenkopi; abundant limonite

staining; some white quartz grains;

irregular bedding; forms steep slope

beneath conglomerate ledge. Uranium

bearing at Shinarump No. 1 mine.......... 7

Total Chinle formation ....................

Shinarump conglomerate absent in line of section. Unconformity (erosional).

\section{Moenkopi formation:}

Shale and mudstone, pale-green (5G7/2) and

moderate-red ( $5 \underline{R} 5 / 4)$; mica along bedding;

bedding poorly developed ............... 1

Shale, grayish-brown (5YR $3 / 2)$; some white

mica; bedding poorly developed............ 6

Sandstone, moderate-red (5R5/4) grading

upward into grayish-green (10GY $5 / 2$ );

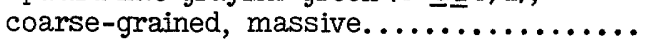

Moenkopi formation-Continued

Sandstone, very pale-orange (10YR8/2) to

moderate reddish-brown (10R4/6); fine-

grained, grading to coarse-grained near

top; angular quartz grains, abundant

muscovite and biotite; thick-bedded; forms

rounded slope; some bleaching along and

across bedding $\ldots \ldots \ldots \ldots \ldots \ldots \ldots \ldots \ldots \ldots . \ldots \ldots \ldots \ldots \ldots$

Total Moenkopi formation. ............. 20

Unconformity( ?).

Cutler formation:

Sandstone and shale, moderate red-brown

(10R4/6); some biotite along bedding;

irregular bedding; forms bench .......... 31

Sandstone, moderate reddish-brown (10R4/6);

medium- to coarse-grained; some mica; very

thickly crossbedded; irregular bleaching along

some beds; weathers rounded; forms ledge..... .

Shale, pale-red (10R6/2); contains mud-crack

fillings; bleached in places ..............

Sandstone, grayish red-purple ( $5 \mathrm{RP} 4 / 2)$ to

moderate-red (5R $4 / 6)$, coarse-grained to

conglomeratic; some white mica and feldspar,

abundant biotite; thin-bedded to low-angle

cross lamination; bleached spheres from

$\frac{1}{4}$ inch to $1.5 \mathrm{ft}$ in diameter-cutting bedding;

friable; forms ledge. (Base of outcrop,

not base of formation) . . . . . . . . . . . 10

Total Cutler formation exposed .........

${ }^{1}$ Rock-color chart prepared by "The Rock-Color Chart Committee," E. N. Goddard and others, National Research Council, Washington, D. C., 1948.

\section{Cutler formation}

Only the upper 66 feet of the total 1,000 feet or more of the Cutler formation of Permian age is exposed in the area mapped. The exposed Cutler consists of medium- to coarse-grained sandstone and muddy sandstone and pale-red shale. Bleaching along fractures and bedding planes is common. Cross-laminated sandstone forms a prominent rounded ledge near the top of the Cutler. Locally along the Moab anticline an angular and erosional unconformity exists between the overlying Triassic Moenkopi and the Cutler. However, the contact between Permian and Triassic rocks in the Shinarump No. 1 mine area is difficult to determine.

\section{Moenkopi formation}

The Moenkopi formation of Early and Middle( ?) Triassic age is 20 feet thick in the measured section near the Shinarump No. 1 mine and pinches out about 450 feet to the north, and a few miles south, the Moenkopi attains a thickness of about 450 feet. Thin-bedded shale and mudstone, and massive sandstone make up the Moenkopi strata. A distinct moderate reddish-brown, abundant mica, and ripple-marking characterize the Moenkopi. The overlying Upper Triassic beds were deposited on an erosional surface formed on the Moenkopi and, in places, on the Cutler.

\section{Shinarump conglomerate and Chinle formation}

The Shinarump conglomerate of Late Triassic age is absent in most of the area mapped. McKnight showed that the Shinarump conglomerate pinches out along an 
irregular east-west line about 15 miles north of the intersection of the Green and Colorado Rivers, and only isolated outcrops of Shinarump conglomerate were mapped north of this line. One such isolated outcrop was mapped in the vicinity of Little Canyon (pl. 1). The Shinarump conglomerate in Little Canyon ranges from 5 to 10 feet in thickness and consists of a friable white coarse-grained to conglomeratic quartz sandstone. The Shinarump becomes discontinuous and lenticular near the northern edge of this outcrop. Siltstone and fine-grained sandstone of the Chinle truncate many of the Shinarump lenses. In an opencut adjacent to the Shinarump No. 1 mine, a white coarse-grained to conglomeratic quartz sand lens corresponding to the Shinarump conglomerate is truncated by the fine-grained sediments containing the ore deposit. Thus, the Shinamump north of the main area of deposition was deposited as small thin lenses or channel fills and was, at least in part, removed before or during the deposition of the overlying Chinle.

The Chinle formation of Late Triassic age is 297 feet thick in the section measured at the mine. In the Seven Mile Canyon area, the Chinle formation may be divided into a lower and an upper unit. The base of a prominent ledge of fine-grained sandstone and limestone pebble conglomerate that is characterized by slump-bedding marks the division of the two units. The lower unit is composed of thin- and irregular-bedded light-green to pale-red siltstone, sandstone, and limestone pebble conglomerate. Much of this unit is covered by talus. A limestone-pebble conglomerate bed about 10 feet above the base of the Chinle serves as a "marker bed" in the Shinarump No. 1 mine area (see section AB-C, pl. 1). The upper unit is composed mostly of palered shale and sandstone which forms for the most part a covered slope. Near the Moab anticline the contact between the Chinle and the Wingate sandstone is a local unconformity.

Many of the uranium deposits in the area between the Green and Colorado Rivers lie near the northern edge or north of the pinchout of the Shinarump conglomerate (fig. 1). In the Seven Mile Canyon area, the uranium deposits lie north of the Shinarump outcrop in Little Canyon. Thus, the uranium deposits are related to the edge of Shinarump deposition on a regional and local scale.

Uranium-bearing rock in the Seven Mile Canyon area is found in many zones in the lower unit of the Chinle, but the ore deposits are found mainly in three zones in the lower 25 feet of the Chinle (section $\underline{A}-\underline{B}-\underline{C}, \mathrm{pl} .1$ ). The Shinarump No. 1 mine is in the lowermost ore zone.

\section{Wingate sandstone}

The Wingate sandstone of Late Triassic age consists of massive yellowish-gray fine-grained sandstone that weathers pale red and is characterized by surface coatings of black desert varnish. In the Seven Mile Canyon area the Wingate, which forms a massive cliff, is over 200 feet thick.

\section{Jurassic rocks}

In the vicinity of the Shinarump No. 1 mine, the Brushy Basin shale member of the Morrison formation of Late Jurassic age is faulted against the Permian and Triassic rocks. The Brushy Basin consists mainly of light-green mudstone. Boulders of the Burro Canyon or Dakota formations of Cretaceous age cover some of the slope of Brushy Basin exposures.

\section{Structure}

The Shinarump No. 1 mine is located on the west flank of the Moab anticline about 700 feet west of the Moab fault. The beds strike N. $15^{\circ} \mathrm{E}$. and dip $8^{\circ} \mathrm{NW}$. at the mine. The joints occur in two sets; one major set strikes N. $5^{\circ}-75^{\circ} \mathrm{W}$. and dips $50^{\circ} \mathrm{NE}$. to vertical, and a minor set strikes N. $35^{\circ}-70^{\circ} \mathrm{E}$. and dips $70^{\circ} \mathrm{SE}$. to vertical.

The Moab anticline, a result of salt intrusion, extends about 15 miles northwest of the Colorado River. The Moab fault, a normal fault, lies a short distance southwest of the crest of the Moab anticline. The fault extends about 30 miles northwest from the Colorado River and has a general trend of about N. $45^{\circ} \mathrm{W}$. nearly parallel to the axis of the Moab anticline. In the Shinarump No. 1 mine area, the fault has a maximum displacement of about 1,800 feet and dips about $65^{\circ} \mathrm{NE}$. and makes a gentle turn to the west near the Shinarump Nos. 1 and 3 mines.

The Moab anticline was in existence at the end of Permian time as shown by the angular and erosional unconformity between the Cutler and Moenkopi formations. McKnight reports that the deformation was renewed in middle Triassic time, prior to the deposition of the orebearing Chinle strata, and was resumed once again during the Laramide orogeny at the end of the Cretaceous period. However, in similar structures on the Colorado Plateau, Stokes and Phoenix (1948) and Shoemaker(1951) find that the intrusion of salt was continuous from Permian to Late Jurassic time; and the author believes the Moab anticline had a similar history. McKnight correlates the faulting along the Moab Valley anticline with the normal faulting of the Wasatch Plateau that is later than preEocene folding and possibly late Tertiary. The Moab fault may be related to the Laramide orogeny or the collapse of the salt structures later in the Tertiary or Quaternary periods. Field relations are so obscure that the dating of the Moab fault is uncertain. Evidence genetically relating the uranium deposits in the Seven Mile Canyon area to the Moab fault is lacking.

\section{HISTORY AND PRODUCTION}

In February 1948 Gordon Babbel and Nicholas Murphy, of Moab, Utah, discovered the Shinarump No. 1 mine. During the following year, claims were staked throughout the Seven Mile Canyon area, and a few tons of ore was shipped in 1949. The mines were idle during 1950 , but in 1951 mining from several prospects was resumed and since then has been continued intermittently. Over a thousand tons of ore was shipped from the Shinarump No. 1 mine between 1948 and January 1953. The Thornburg Mining Company, Grand Junction, Colo. owns the Shinarump mines Nos. 1,3 , and 4.

\section{ORE DEPOSTTS}

Copper-bearing rocks occur separate from uraniumbearing rocks in the Shinarump No. 1 mine area. Copperbearing rock is found along the Moab fault and in a talus 
block that is thought to be Dakota sandstone of Cretaceous age. Copper carbonates are found along fractures and bedding planes as well as disseminated in sandstone in a prospect in the talus block. Fractured rock along the fault in an abandoned shaft at the base of the talus block contains copper carbonates. The copper prospects are not commercial in size or grade. Uranium is not known to be associated with the copper.

The uranium-bearing material in the Shinarump No. 1 mine area occurs mainly in three zones in the lower 25 feet of the Chinle formation. The zones include, in ascending order, a basal siltstone unit, the top of the overlying limestone-pebble conglomerate "marker bed," and an irregular dominantly siltstone zone 5 to 10 feet above the conglomerate.

The highest zone consists of small calcareous nodules of rich concentrations of uranium minerals associated mainly with wood and arbonaceous rubble in greenish siltstone and minor limestone-pebble conglomerate beds. Some wood is almost completely replaced by uraninite, which has been altered to becquerelite in places. If the frequency of occurrence of nodules is great enough, the deposit can be economically mined. At the Shinarump No. 3 mine this zone, although discontinuous, is as much as 3 feet thick.

The middle zone is in the upper part of the conglomerate "marker bed" where limestone pebbles are. rimmed and replaced in part by uraninite. This conglomerate is mineralized north of the Shinarump No. 1 mine (pl. 1). Most of the uranium-bearing material in these two zones is associated with calcite nodules or limestone pebbles, carbonaceous material, and gray or green rock.

The Shinarump No. 1 mine is in the lowermost ore zone, which is made up mostly of siltstone with some interbeds of mudstone, sandstone, and conglomerate and ranges from 5 to 10 feet in thickness. Where this zone is mineralized, the beds are bleached from red to gray and green. The saucer-shaped area of bleached ore-bearing beds extends from 1 to 15 feet laterally beyond the limits of the deposit. The limestone-pebble conglomerate "marker bed" is fairly uniform and massive throughout the area except above the Shinarump No. 1 deposit and above the deposit in the lower uranium-bearing zone at the Shinarump No. 4 prospect. the thinning and less massive character of this "marker bed" above the deposits in the lower zone may be significant in prospecting for ore in the Seven Mile Canyon area.

On the basis of the major metal content, uranium deposits of the Colorado Plateau may be divided into vanadium-uranium, copper-uranium, and uranium. The Shinarump No. 1 deposit contains only minor amounts of copper and vanadium and thus, is a uranium deposit. Oxidation of the uranium deposits such as the Shinarump No. 1 is generally slight, and deposits of this type are less obvious to the prospector because secondary uranium minerals are scarce at the outcrop.

\section{MINERALOGY}

Other writers have studied the mineralogy of the Seven Mile Canyon area (Weeks, 1952, and Rosenzweig, in report by Droullard and Jones, 1952). Only the mineralogy of the Shinarump No. 1 mine is discussed here.
Uraninite (pitchblende), ideally $\mathrm{UO}_{2}$ (commonly contains $\mathrm{UO}_{3}$ ), is the principal uranium mineral. It occurs as microscopic grains mixed with chalcocite and other sulfides replacing carbonaceous material and disseminated in siltstone. Rich concentrations of uraninite occur in seams as much as a half an inch thick along bedding planes.

Some uraninite is slightly altered to a burntorange material resembling gummite, and halos of this material are present about unaltered uraninite. Schroeckingerite $\mathrm{NaCa}_{3}\left(\mathrm{UO}_{2}\right)\left(\mathrm{CO}_{3}\right)_{3}\left(\mathrm{SO}_{4}\right) \mathrm{F} .10 \mathrm{H}_{2} \mathrm{O}$, a pale yellowish-green mineral, and becquerelite $2 \mathrm{UO}_{3} .3 \mathrm{H}_{2} \mathrm{O}$, a yellowish-orange mineral, occur along fractures and bedding planes near the edges of the deposit nearest the surface. No secondary vanadium-uranium minerals were found.

The sulfides present in the ore are chalcocite, pyrite, bornite, chalcopyrite, and blue chalcocite (digenite?, solid solution of covellite and chalcocite). All the sulfides, except the blue chalcocite, occur as scattered grains in both barren and uranium-bearing rock. Chalcocite and pyrite are more abundant in the uranium-bearing rock. Uraninite is associated with all the sulfides but most commonly with pyrite and chalcocite. Some malachite is found coating chalcocite.

Gangue materials include barite, calcite, gypsum, and carbonaceous matter. Carbonaceous matter in the form of leaves, twigs, and small pieces of wood is most abundant right above the uranium-bearing beds. There is no megascopic difference in the physical properties of barren and radioactive carbonaceous matter. Limonite is rare, whereas hematite is abundant in places.

In both barren and uranium-bearing rock, the quartz has been etched and crushed. Bornite, chalcocite, pyrite, uraninite, calcite, and barite are later than etching. Fractures in crushed quartz are either void or contain calcite. Uraninite, pyrite, and chalcocite are associated with poorly sorted parts of a rock and, in general, follow bedding planes. Stringers of these minerals wrap around and are deflected by the large quartz grains. Many blebs of uraninite and pyrite are zoned with the uraninite forming rims about finegrained pyrite. Pyrite was observed in very fine fractures in siltstone. Chalcocite occurs in vertical veinlets as much as half a millimeter wide that strike eastwest. Nuclear-track plates on thin sections of these veinlets indicated the absence of radioactive minerals. However, copper and uranium minerals extend outward along bedding planes away from these fractures. Calcite and more rarely barite have filled voids in the rock.

Paragenesis of uraninite and sulfides from the Shinarump No. 1 mine is given in figure 2. The conventional line diagram is shown with the circular diagram (Robertson and Vandeveer, 1952) to compare the two methods of showing paragenesis. The circular diagram shows the minerals observed in contact; pyrite, for example, was observed in contact only with uraninite and chalcocite. The line diagram shows that some pyrite is later than chalcopyrite even though the two were never observed in contact. It is difficult to show two groups of simultaneous minerals in the circular diagram. The two diagrams, thus, complement each other. 


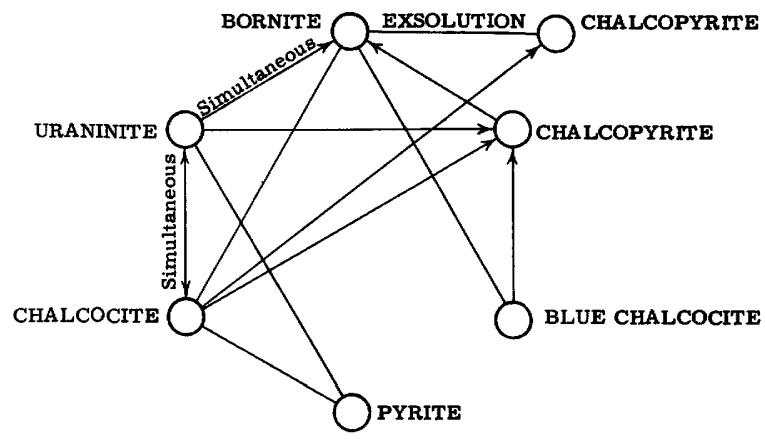

Simultaneous deposition

$\stackrel{\text { Simultaneous }}{\longrightarrow}$ Simultaneous with replacing tendency shown by arrows

$\rightarrow$ Replacement, example: chalcopyrite replacing bornite

Lines connect only those minerals observed in contact.

Minerals arranged clockwise in approximate order of

deposition. Modified after Robertson and Vandeveer (1952)

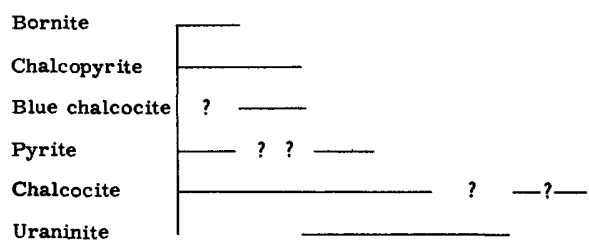

Figure 2. - Paragenesis of uraninite and sulfide minerals, Shinarump No. 1 mine, Grand County, Utah.

In general, in the Shinarump No. 1 deposit uraninite is later than or simultaneous with most sulfides. Chalcocite may be of two ages with some being later than uraninite. Rosenzweig (in Droullard and Jones, 1952), writing about the Seven Mile Canyon area, states: "It appears that the time of formation of the copper sulfides followed closely or possibly overlapped that of uraninite." Thus, the paragenetic relationship of uraninite and sulfides in the Shinarump No. 1 deposit found by this study is not in complete agreement with the Seven Mile Canyon area taken as a unit.

Photomicrographs in figure 3 show some of the paragenetic relationships. Chalcocite crosscutting uraninite that has completely replaced wood is shown in photomicrograph A. Photomicrographs $\underline{C}$ and $\underline{D}$ show the relationship of etched quartz grains, uraninite, and chalcocite. Note the uraninite-free areas surrounding the etched quartz grains. A peripheral line of uraninite is concentric with the shape of the etched quartz grain. Stringers of uraninite radiate from these peripheral lines. It appears that cracks may have formed in the chalcocite and were later filled with uraninite. Other, but less likely, explanations are that these crack fillings represent the replacement of crushed or distorted cellular structure of wood or that chalcocite replaced quartz grains in places and the uraninite replaced the interstitial clay material. Photomicrograph $E$ shows a texture interpreted as caused by the exsolution of chalcopyrite in bornite. Photomicrograph $F$ of a thin section of sample no. 5 shows the zoning of uraninite and chalcocite about a pyrite core.

Blue chalcocite observed in one polished section may be digenite, which is a solid solution of covellite and chalcocite; however, the common digenite texture is absent. Wandke (1953) points out that if the specimen is heated above $68^{\circ} \mathrm{C}$, during the preparation of the sample, digenite may be formed from covellite and chalcocite. However, covellite was not observed so that either all covellite was adjacent to chalcocite and transformed or digenite was present before preparation of the sample. The author prepared the specimens in sealing wax which may not have heated the specimen above the critical temperature. The problem of blue chalcocite (digenite?) is important from the standpoint of temperature of ore formation (Buerger, 1941).

\section{PETROLOGY}

Samples of barren and uranium-bearing rock from the Shinarump No. 1 mine (table 1) were studied in thin section, slides of light and heavy grains, and by size analysis. Generally, the ore-bearing rocks are siltstone and fine-grained sandstone that are more poorly sorted than the barren siltstone and fine-grained sandstone. Barren rocks include siltstone, fine- to coarse-grained sandstone, limestone-pebble conglomerate, and mudstone. Reworked siltstone and sandstone pebbles and grains from the Moenkopi are common in many beds. Visually, packing is good in both barren and ore-bearing rocks. Calcite and clayey material cement barren and ore-bearing rock. The grains are usually subangular to well rounded.. Angular and broken feldspar is abundant in one uranium-bearing siltstone sample.

The composition of light constituents, specific gravity less than 2.9 , of the uranium-bearing and barren Chinle samples is mostly quartz and chert, and minor amounts of microcline, muscovite, orthoclase, and oligoclase are present. Some chert grains contain pyrite cubes. Heavy nonopaque detrital minerals, specific gravity greater than 2.9, include mostly zircon, tourmaline, and biotite, with minor amounts of rutile, chlorite, spinel, garnet, and staurolite. Opaque detrital minerals include ilmenite, leucoxene, and hematite. Authigenic barite is abundant in both barren and uraniumbearing rock and has been precipitated in open spaces. Counts of the heavy detrital minerals from barren and uranium-bearing samples show no correlation of any mineral or group of minerals with uranium-bearing rock.

$\mathrm{X}$-ray spectrometric determinations of material smaller than 4 microns, from barren and ore-bearing samples made by the trace elements laboratory of the Geochemistry and Petrology Branch of the Geological Survey, indicate the presence of quartz (fine cryptocrystalline?), hydromica, and kaolin in every sample. Some samples contain small amounts of feldspar, calcite, dolomite, chlorite, and montmorillonite. 

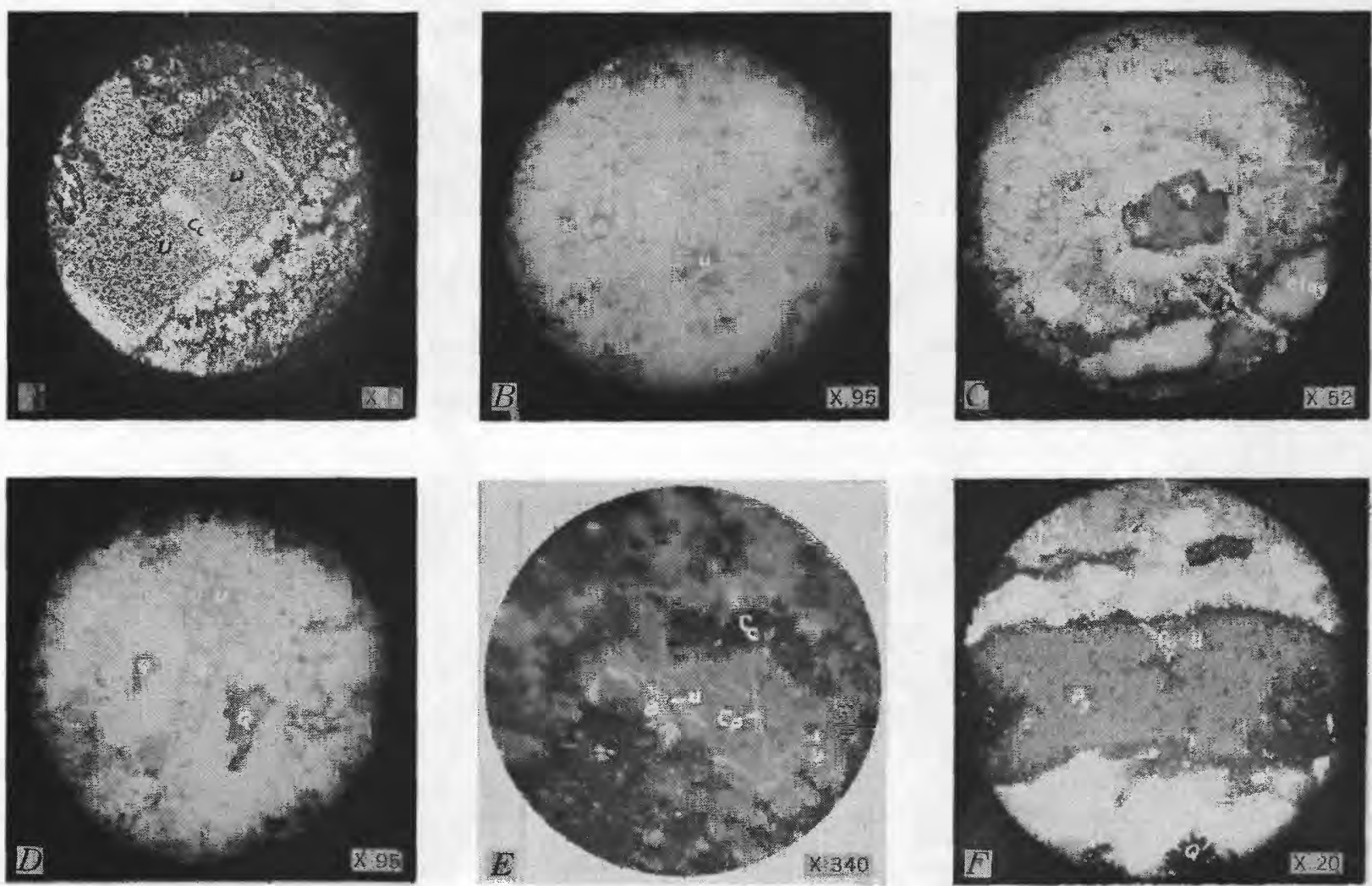

Figure 3.-Photomicrographs of polished and thin sections from the Shinarump No. 1 mine, Grand County, Utah. A, Polished section of sample 22 showing replacement of wood by uraninite (U, light gray) and chalcocite ( $\mathrm{Cc}$, white). B , Polished section of sample 23 showing relation of chalcocite (Cc, white) and Uraninite (U). $\underline{C}$ and $\underline{D}$, Polished section of sample 23 showing etched quartz (Q, dark gray) grains surrounded by chalcocite ( $\underline{\mathrm{Cc}}$, white), which is free of uraninite (U, light gray), and uraninite filling minute cracks in chalcocite that are oriented radially about the quartz. E, Polished section of sample 26 showing texture interpreted as caused by exsolution of chalcopyrite ( $\mathrm{Cp}$, white) in bornite ( $\underline{\mathrm{B}}$, light gray), replacement of bornite by chalcocite (Cc, dark gray), and uraninite (U, medium gray) cutting all other minerals. E, Thin section of sample 5 with reflected and transmitted light showing bleb of minerals, pyrite ( $\underline{\mathrm{Py}}$, light gray) surrounded by border of chalcocite and uraninite (Cc- $\mathrm{U}$, black) in sandstone. Note encroachment of quartz ( $Q$, white) by ore minerals. 
Table 1.-Samples from Seven Mile Canyon area

\begin{tabular}{|c|c|}
\hline $\begin{array}{c}\text { Sample } \\
\text { no. }\end{array}$ & Specific location ${ }^{1}$ \\
\hline 1 & Wall MN- \\
\hline 2 & (nd \\
\hline 3 & 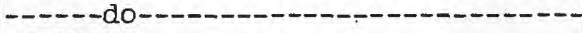 \\
\hline 4 & Wall GH \\
\hline 5 & Wall $\overline{\mathrm{MN}}-\cdots$ \\
\hline 6 & - n $\overline{\mathrm{do}}-\cdots-\cdots$ \\
\hline 7 & 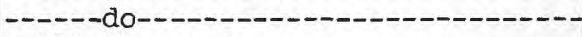 \\
\hline 8 & -Wall CD \\
\hline 9 & 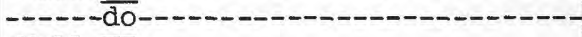 \\
\hline 10 & Wall EF-n \\
\hline 11 & 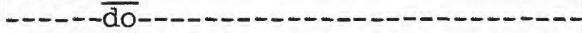 \\
\hline 12 & Wal1 MN \\
\hline 13 & Wall $\overline{\mathrm{EF}}-\cdots$ \\
\hline 14 & 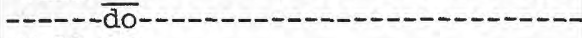 \\
\hline 15 & Wall CD \\
\hline 16 & $-\cdots \overline{\mathrm{do}}-\boldsymbol{n}$ \\
\hline 17 & 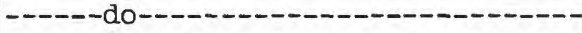 \\
\hline 18 & 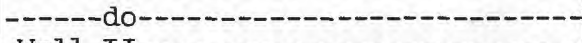 \\
\hline 19 & Wall IJ-n \\
\hline 20 & Copper Queen ${ }^{2}$ \\
\hline 21 & Copper prospect ${ }^{2}$ \\
\hline 22 & 20 feet $N \cdot 3^{0}$ W. of station $R^{3}$ \\
\hline 23 & 28 feet $N \cdot 11^{\circ}$ W. of station $R^{3}$ \\
\hline 24 & Wall CD-- \\
\hline 25 & $\mathrm{Kellog}$ No. 1 claim² \\
\hline 26 & Third stope from left ${ }^{3}$ \\
\hline 27 & North portal ${ }^{3}$ \\
\hline 28 & 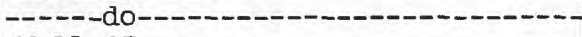 \\
\hline 29 & Wall IJ-n \\
\hline 30 & Wall $\overline{\mathrm{K}}-\ldots$ \\
\hline 31 & Little Canyon ${ }^{2}$ \\
\hline
\end{tabular}

${ }^{1}$ Plate 2 unless otherwise noted.

Description
Uranium-bearing unbleached siltstone stringers.
Uranium-bearing sandstone; very fine to coarse grained.
Limy siltstone.
Highly radioactive carbonaceous material.
Uranium-bearing muddy siltstone.
Uranium-bearing silty sandstone.
Uranium-bearing siltstone.
Uranium-bearing silty sandstone.
Uranium-bearing siltstone.
Muddy siltstone; forms back of mine.
Limestone pebble conglomerate above ore.
Uranium-bearing siltstone.
Limy sandstone below ore.
Barren siltstone.
Uranium-bearing siltstone north of fracture.
Barren siltstone north of fracture.
Altered siltstone south of fracture.
Unaltered siltstone south of fracture.
Nonradioactive carbonaceous material.
Secondary copper minerals in Moab fault zone.
Copper-bearing material from Moab fault zone.
Fractures filled with chalcocite.
Uraninite and chalcocite layer.
Conglomerate below ore.
Uranium-bearing sandstone from the Morrison formation.
Uraninite, bornite, chalcocite in seam.
Barren siltstone from the Chinle formation.
Barren sandstone from the Shinarump conglomerate.
Uranium-bearing siltstone, chalcocite veins.
Uranium-bearing siltstone and sandstone.
Conglomeratic sandstone from the shinarump conglomerate.
-

${ }^{2}$ Plate 1.

${ }^{3}$ Figure 7.
Figures 4, 5, and 6 show the results of size analysis. Sample 31 (figs. 4, 5) came from the Shinarump conglomerate in Little Canyon (pl. 1), and sample 28 (figs. 4, 5) was taken from near the mine from a lens of a similar sandstone which has been eroded and cut out by the overlying ore-bearing siltstone of the Chinle. The two samples have the same mineral suite, which differs from the suite in the Chinle samples. The frequency and cumulative curvew of the two samples are similar. It is concluded that the lens near the mine is an erosional remnant of Shinarump near the margin of Shinarump deposition. The coarse grains in several samples cause bimodal frequency curves (fig. $5 \underline{A}$, samples 7, 8; fig. $5 \underline{C}$, sample 24), which suggest a source for the coarse grains similar to the Shinarump or that the coarse grains came from the Shinarump that was partly eroded before the deposition of the Chinle. Uranium-bearing samples are more poorly sorted than barren samples.

A special study was made of a single siltstone bed along wall $\underline{C}-\underline{D}(\mathrm{pl}$. 2) to find what changes might be evident in a mineralized and bleached bed. A fracture between the uraniumbearing rock and the unaltered rock is parallel to the truncated ore as well as the line between bleached and unbleached rock. The possible effect of this fracture on mineralization was also studied.
The results of the size analysis of 4 samples are given in figure 6 . Study of frequency curves and thin sections shows the siltstone to be more poorly sorted to the north, on the mineralized side of the fracture, than to the south. Study of the light and heavy detrital minerals shows no correlation of any mineral or group of minerals with the uranium-bearing part of the siltstone. However, spectrographic analysis of these samples indicates a marked increase of some elements in uranium-bearing rock over barren rock but no difference between bleached and unbleached rock. The increase of some elements in uranium-bearing rock is not reflected as a halo about the uraniumbearing rock. The position of the fracture with relation to uranium-bearing and bleached rock is probably a coincidence as the spatial relationship of this fracture along strike shows no similar relationship to uranium-bearing or barren rock.

The results of the petrographic study show the uranium-bearing rock to be more poorly sorted than barren rock. Detrital grains in the uraniumbearing and barren rock are essentially the same in mineralogy and quantity. The mineralogy of the coarse fractions of the ore-bearing beds indicate original source rocks to be schists and acid to intermediate igneous rocks. The orebearing beds are thought to be mostly secondcycle and partly third-cycle sediments. 


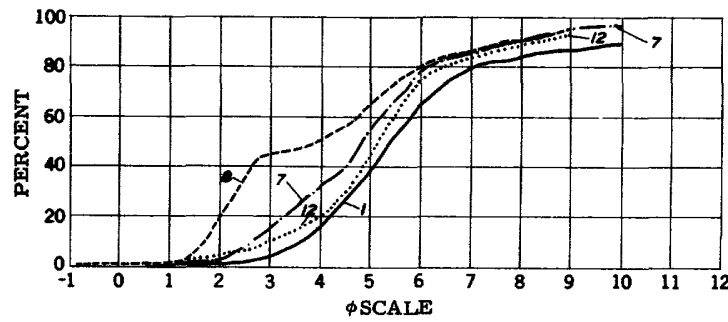

A. Ore-bearing Chinle samples

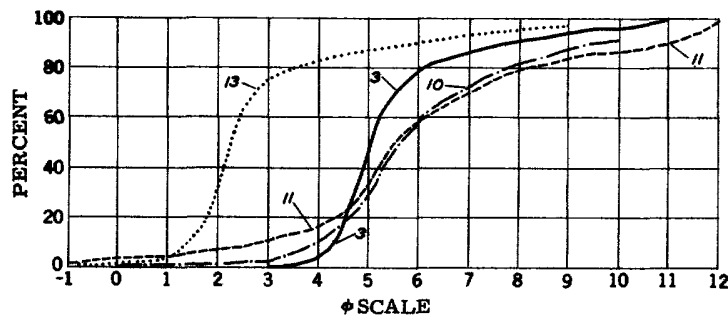

B. Barren Chinle samples

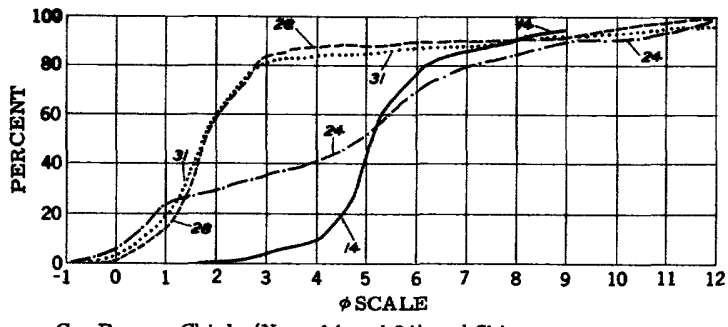

C. Barren Chinle (Nos. 14 and 24) and Shinarump (Nos. 28 and 31) samples

Figure 4. -Cumulative curves of grain size of samples from the Seven Mile Canyon area, Grand County, Utah. Scale is the phi scale of Krumbein (1934).

\section{HABITS OF ORE BODIES}

The Shinarump No. 1 mine was mapped in plan on a scale of 1 inch equals 20 feet (fig. 7), and maps of walls and faces were made on a scale of 1 inch equals 5 feet (pl. 2). Plate 1 and figure 7 show sample locations. Uranium minerals are not generally visible, so a Geiger counter was used to outline the extent of uranium-bearing rock. Arbitrary cutoffs in counts-per-minute were used to appraise the uranium values of the mine as stated in figure 7.

The uranium-bearing rock is almost a continuous lenticular layer that approximately follows the bedding but locally and in small detail cuts across the bedding. Ore-grade material is in discontinuous lenses (ore shoots) which tend to be elongate about north-south. The ore averages 1 or 2 feet in thickness with a maximum of about 5 feet. The grade of the ore ranges from 0.10 percent to 1.00 percent $\mathrm{U}_{3} \mathrm{O}_{8}$ with small masses greater than
1.00 percent $\mathrm{U}_{3} \mathrm{O}_{8}$. Near the edges of the deposit, the ore layer tends to rise in the beds so that the deposit in cross section is saucer shaped (maps of mine walls $\mathrm{AB}, \mathrm{CD}, \mathrm{pl}$. 2). The north edge of the deposit has an east-west trend. The orebearing beds lie essentially flat and fill irregularities of an erosional surface. Structural contours on the top of the Moenkopi indicate that no channel scour is present in the vicinity of the mine.

Most of the deposit is composed of siltstone and fine-grained sandstone impregnated with microscopic grains of uraninite, chalcocite, and pyrite. High-grade layers as much as half an inch in thickness of chalcocite and uraninite are found along some bedding planes. In one place, the high-grade ore is concentrated along the base of a bed that overlies a less permeable appearing bed (pl. 2, map of mine wall IJ). Vertical veinlets of chalcocite lead upward to this concentration.

The original color of sediments that contain the deposit is thought to have been red that was

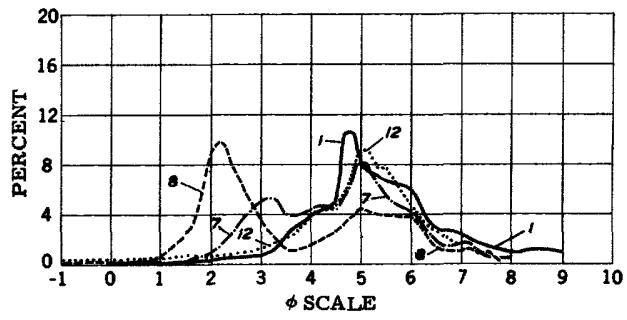

A. Ore-bearing Chinle samples

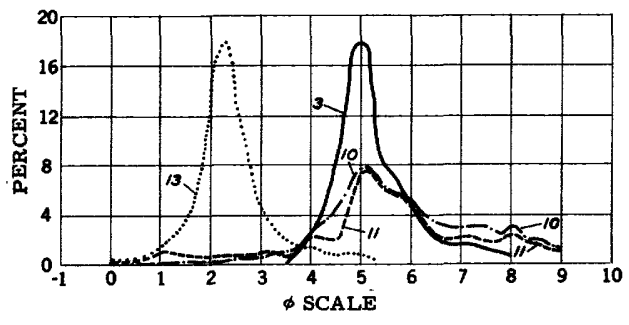

B. Barren Chinle samples

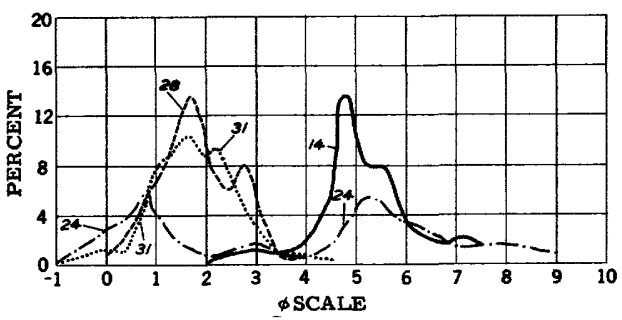

C. Barren Chinle (Nos. 14 and 24) and Shinarump (Nos. 28 and 31 ) samples

Figure 5. - Frequency curves of grain size of samples from the Seven Mile Canyon area, Grand County, Utah. Scale is the phi scale of Krumbein (1934). 

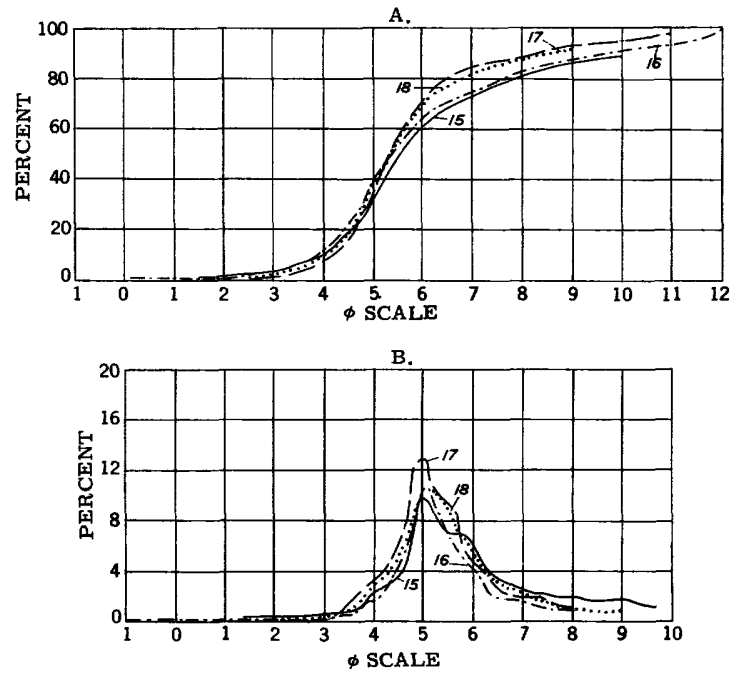

C.

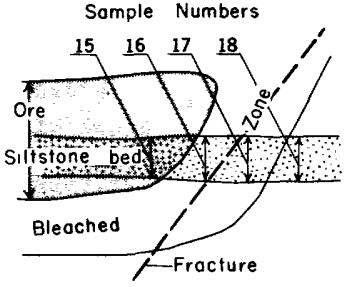

Figure 6. -Curves of ore-bearing and barren siltstone from Shinarump No. 1 mine, Grand County, Utah. $\underline{A}$, Cumulative curve; $\underline{B}$, frequency curve; $\underline{C}$, Source of samples. Scale is the phi scale of Krumbein (1934).

altered later by solutions which may have deposited the ore. The only apparent change brought about by the alteration was a bleaching of red to gray and green. The bleaching extends 1 to 15 feet beyond the limits of the mineralized rock and locally the limit parallels the shape of the mineralized layers in detail.

Prospecting guides to additional deposits similar to the Shinarump No. 1 in the Seven Mile Canyon area are (1) presence of bleached siltstone; (2) presence of carbonaceous matter; (3) presence of copper sulfides, especially chalcocite; and (4) thinning of the limestone-pebble conglomerate "marker bed." The last ore guide is probably only of local importance.

\section{SPECTROGRAPHIC STUDY}

Semiquantitative spectrographic analyses of 20 samples were examined statistically. ${ }^{1}$ The

\footnotetext{
${ }^{1}$ Reported assays by semiquantitative spectrographic analysis were made by the trace elements laboratory of the Geochemistry and Petrology Branch of the Geological Survey at Denver. The assays that are normally expressed in groups of powers of 10 were reported in subgroups whose theoretical range is shown on page 14. The geometric mean was obtained by applying a simple formula, which may be found in any elementary text on statistics, such as Waugh (1943), to the midpoints of the subgroups (class marks).
}

geometric mean values in percent of 32 elements contained in groups of samples from barren and uraniumbearing rock from the Shinarump No. 1 mine, coppexbearing rock from nearby copper prospects in the Moab fault, and uranium-bearing rock from the Kellog No. 1 mine (pl. 2) in the Morrison formation are shown in table 2 . The samples were tested for 26 other elements but none were detected. In all groups of samples, common rock forming elements show no systematic variation. Comparison of barren and uranium-bearing rock from the Shinarump No. 1 mine shows a substantial increase in the uranium-bearing rock of the elements boron, beryllium, cobalt, copper, gallium, molybdenum, nickel, lead, silver, uranium, vanadium, yttrium, and zinc. In the uranium-bearing samples of the Shinarump No. 1 mine, mean values for barium, copper, vanadium, and titanium are as high as the grade of much of the uranium ore produced from the mine. The few samples from the copper deposits show affinities to the barren rock at the Shinarump No. 1 mine except for the element silver (see table 2). The values from a single sample of uranium-bearing rock from the Kellog No. 1 mine in the Morrison formation show similarities to the uranium-bearing rock from the Shinarump No. 1 mine.

Selenium content cannot be determined by spectrographic methods, but it is suspected to be present in considerable quantity near the uranium and copper mines and along the Moab fault because selenium and sulfur indicator, or tolerant, plants are present in these areas.

Chemical and radioactivity analysis of uranium shows the uranium ore to be nearly in equilibrium. This equilibrium and the general lack of secondary minerals indicate that the ore is relatively unoxidized and that ground water has had little effect upon the ore.

High radioactivity is found in some seams of carbonaceous material. Comparison of the spectrographic analysis of megascopically identical, relatively nonradioactive materials with the analysis of highly radioactive carbonaceous materials (sample nos. 19 and 4, respectively) shows the radioactive carbonaceous material to contain at least one order more of barium, zinc, cobalt, nickel, uranium, and silver. This is similar to the differences in the mean metal values of barren and of uranium-bearing rock in the mine. However, in the radioactive carbonaceous material, the values of these elements are high; barium assays about 30 pexcent, zinc assays about 5 percent, and cobalt and nickel assay over 1 percent. The great inequilibrium of the radioactive carbonaceous material indicated by the comparison of 6.6 percent equivalent value for uranium and 0.17 percent chemical value for uranium is due to radon. The relatively nonradioactive carbonaceous material is nearly in equilibrium.

The results of the spectrographic analyses indicate that the solutions which deposited the copper in the Moab fault zone were probably different than those which deposited the uranium in the Chinle and Morrison formations. The uranium-bearing solutions probably contained important amounts of barium, vanadium, uranium, and copper as well as lesser amounts of strontium, chromium, boron, yttrium, lead, and zinc. The abundance of sulfide minerals in the deposits indicate that the solutions were probably reducing in character and sulfur rich. 


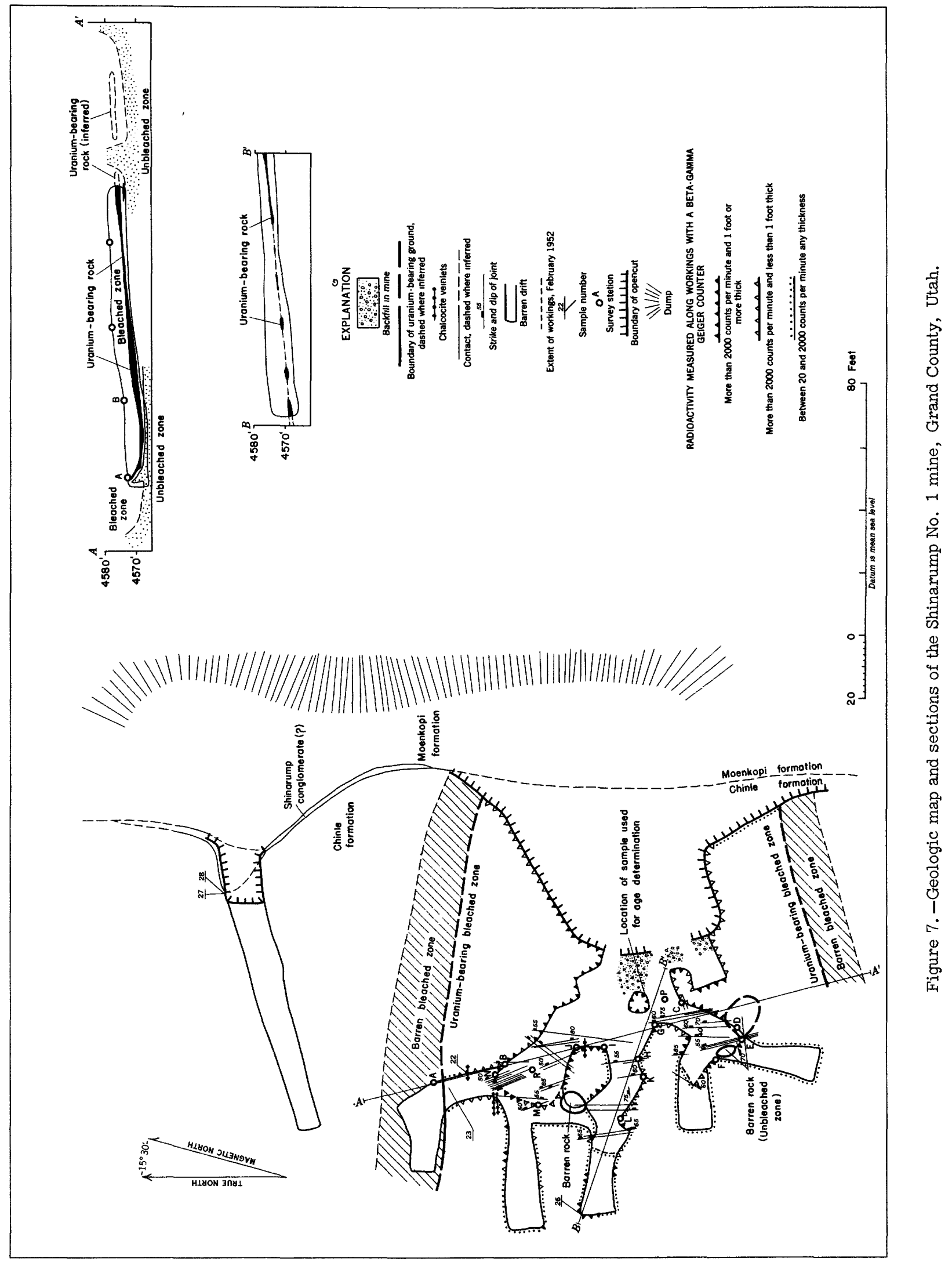


Table 2.-Geometric mean values (in percent) of elements contained in barren and uranium-bearing rock from the Shinarump No. 1 mine, copper-bearing rock from nearby copper deposits, and uraniumbearing rock from a nearby deposit in the Morrison formation.

[Geometric mean in percent calculated from spectrographic analysis. Looked for but not found: As, Au, Bi, Ce, Ge, In, Ir, $\mathrm{Hf}, \mathrm{Hg}, \mathrm{Li}, \mathrm{Nb}, \mathrm{Os}, \mathrm{P}, \mathrm{Pd}, \mathrm{Pe}, \mathrm{Re}$,

\begin{tabular}{|c|c|c|c|c|c|c|c|c|c|}
\hline Element & $\begin{array}{c}\text { Chinle } \\
\text { barren } \\
\text { rock }\end{array}$ & $\begin{array}{l}\text { Chinle } \\
\text { uranium- } \\
\text { bearing } \\
\text { rock }^{2}\end{array}$ & $\begin{array}{l}\text { Copper- } \\
\text { bearing } \\
\text { rock }^{3}\end{array}$ & $\begin{array}{c}\text { Morrison } \\
\text { uranium- } \\
\text { bearing } \\
\text { rock }^{4}\end{array}$ & Element & $\begin{array}{c}\text { Chinle } \\
\text { barren } \\
\text { rock }\end{array}$ & $\begin{array}{c}\text { Chinle } \\
\text { uranium- } \\
\text { bearing } \\
\text { rock }\end{array}$ & $\begin{array}{l}\text { Copper- } \\
\text { bearing } \\
\text { rock }^{3}\end{array}$ & $\begin{array}{l}\text { Morrison } \\
\text { uranium- } \\
\text { bearing } \\
\text { rock }^{4}\end{array}$ \\
\hline $\begin{array}{l}\mathrm{S} 1 \\
\mathrm{Al} \\
\mathrm{K} \\
\mathrm{N} \mathrm{a}-\end{array}$ & $\begin{array}{l}30 \\
2 \\
1 \\
.1 \\
1.03 \\
5 \\
.6 \\
.07 \\
.02 \\
.2 \\
.02 \\
.006 \\
.0004 \\
.002 \\
(5)\end{array}$ & $\begin{array}{l}30 \\
4 \\
2 \\
.3 \\
2.02 \\
.02 \\
1 \\
.2 \\
.03 \\
.2 \\
.04 \\
.01 \\
.002 \\
.002 \\
0\end{array}$ & $\begin{array}{l}30 \\
2 \\
.4 \\
.07 \\
.5 \\
.03 \\
2 \\
.2 \\
.1 \\
.007 \\
.06 \\
.02 \\
.002 \\
0 \\
0 \\
0\end{array}$ & $\begin{array}{l}30 \\
.3 \\
.3 \\
.06 \\
.03 \\
2.3 \\
.02 \\
.02 \\
.2 \\
.02 \\
.02 \\
.0002 \\
0 \\
0\end{array}$ & 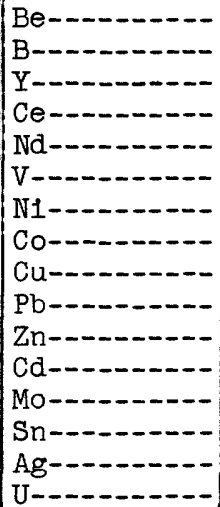 & $\begin{array}{l}0.0001 \\
.01 \\
.002 \\
(5) \\
(5) \\
.02 \\
.0009 \\
.0003 \\
.05 \\
.002 \\
0 \\
0 \\
(5) \\
0 \\
(5) \\
0\end{array}$ & $\begin{array}{l}0.001 \\
.05 \\
.01 \\
0 \\
0 \\
.2 \\
.008 \\
.008 \\
.2 \\
.03 \\
.03 \\
(5) \\
.003 \\
(5) \\
.0007 \\
1\end{array}$ & $\begin{array}{l}0 \\
.005 \\
.001 \\
0 \\
0 \\
.03 \\
.002 \\
.002 \\
5^{.003} \\
0.003 \\
0.001 \\
0^{.002} \\
0\end{array}$ & $\begin{array}{l}0 \\
.006 \\
.003 \\
0 \\
0 \\
.2 \\
.003 \\
.02 \\
2.6 \\
.6 \\
.2 \\
.003 \\
.02 \\
0 \\
.02 \\
.06\end{array}$ \\
\hline
\end{tabular}

${ }^{1}$ Result of analyses of 10 samples from Shinarump No. 1 mine.

${ }^{2}$ Result of analyses of 7 samples from Shinarump No. 1 mine.

${ }^{3}$ Result of analyses of 2 samples.

\section{AGE DETERMINATIONS OF URANINITE}

The following is a resumé of the lead-uranium age determinations of some uraninite specimens from Triassic and Jurassic sedimentary rocks of the Colorado Plateau by Stieff and Stern (1953). As part of their study on the origin of uranium deposits in the Triassic and Jurassic sedimentary rocks of the Colorado Plateau, 21 samples of uraninite from 13 deposits were collected for $\mathrm{Pb}^{206 \mathrm{U}^{236}}$ age determinations. These uraninites are believed to be the most reliable of more than 100 samples from the plateau on which age determinations have been made. The average age of the uraninites from the Morrison is lower by a factor of two than the best estimate of the age for the Morrison formation. The average age of the uraninite samples including the Chinle formation in the one from Shinarump No. 1 mine (fig. 7), from the Shinarump conglomerate is lower by a factor of three than the best estimate of the age of the Shinarump conglomerate. The average age of samples from the Upper Jurassic Morrison formation does not differ significantly from the average age of samples from the Upper Triassic Shinarump conglomerate. The average age of samples from the two formations agree very closely with the best available estimates for the age of the end of the Cretaceous or the beginning of the Tertiary periods.

\section{Stieff and 'Stern conclude that-}

Most of the lead-uranium data that we have obtained strongly suggests that the deposits are not syngenetic but were emplaced in the sediments during the Tertiary, long after the enclosing sediments were laid down. If, however, the deposits are syngenetic in origin, an event must have occurred at the end of the Cretaceous or during the Tertiary which completely redistributed the uranium and localized the ore in its present sites.

\footnotetext{
${ }_{5}^{4}$ Values of 1 sample.

${ }^{5}$ Detected in too few samples to take geometric mean.
}

\section{ORIGIN OF DEPOSIT}

For many years the uranium deposits on the Colorado Plateau, which included mostly oxidized vanadium-uranium deposits (carnotite-type) of the Morrison and Shinarump formations, were considered to have been formed shortly after the deposition (penesyngenetically) of the enclosing sediments (Fischer, 1942). However, owing to concentrated investigations during the past several years and to the discovery of relatively unoxidized uranium deposits of the vanadium-uranium, copper-uranium, and uranium types in many different formations of the Colorado Plateau and adjoining regions, several hypotheses that had been previously discarded are being reconsidered. These include hydrothermal origin, downward leaching of uranium from volcanic strata, and petroliferous origin. A brief statement of the fundamentals of each of the hypotheses follows.

The penesyngenetic hypothesis may be best expressed by quoting Fischer.

The primary ore minerals are thought to have been introduced into their present position not long after the sands were deposited. If this is true, the metals were probably transported and deposited by ground waters, and the ores were probably localized by delicate chemical and physical conditions that now cannot be definitely recognized. This hypothesis probably requires at least three separate periods of ore deposition, to account for the ore in the Shinarump, Entrada, and Morrison formations.

Since his studies, deposits have been found in the Hermit, Cutler, Moenkopi, Chinle, Todilto, Dakota, Mesaverde, Wasatch, Uinta, and other formations on the Colorado Plateau.

The concept of a hydrothermal origin of the uranium deposits received impetus from the results of age determinations of uraninite specimens from uranium deposits of the Colorado Plateau (Stieff and Stern, 1953). The hydrothermal 
hypothesis suggests that uranium-bearing solutions were related to Tertiary igneous activity and that solutions moved vertically along fractures and then laterally until reaching favorable loci where the uranium was deposited.

Downward leaching of uranium from volcanic strata has been suggested because of the thick series of strata containing abundant volcanic debris that overlie both the Salt Wash sandstone member of the Morrison formation and the Shinarump conglomerate. Waters and Granger (1953) suggest that the devitrification of this volcanic material provides the silica for silicification of wood as well as for the addition of silica in the ore-bearing sandstones. Others (Proctor, 1949, and Love, 1952) have suggested these and other strata containing volcanic material as source rocks for the uranium.

Uranium-bearing material and petroleum have the same suite of trace metals, and thus a common origin has been suggested (R. Erickson, oral communication).

Any hypothesis must account for all of the following relations or facts before it can be accepted as a satisfactory explanation of the origin of the deposits:

(1) Sedimentary structures, such as channels and lenses, and sedimentary features such as bedding planes, graded bedding, and impervious barriers controlled the location of most of the ore deposits.

(2) Bleaching of red mudstones to gray or green accompanies most deposits.

(3) Most deposits are in continentaltype sediments.

(4) Most deposits are associated with carbonaceous material.

(5) The common age indicated by age determinations.

(6) The persistent assoclation of uranium with vanadium in the Morrison formation and the variety of element associations including vanadium and copper in the Triassic formations.

The origin of the Shinarump No. 1 deposit, which is clearly later than enclosing sedimentary rocks, is thought to be hydrothermal. Age determinations by Stieff and Stern (1953) indicate that the uraninite in this deposit formed at the end of the Cretaceous or the beginning of the Tertiary periods. The mineral assemblage, particularly the presence of uraninite, blue chalcocite (digenite ?), and bornite-chalcopyrite solid solution, strongly suggests a temperature of formation warmer than the temperature of normal ground water. The localization of the ore is related to the pinchout of the Shinarump conglomerate on a regional and local scale and to sedimentary features such as bedding planes, graded bedding, and sorting, within orebearing beds. Carbonaceous and clayey material may have acted as a chemical and physical attraction for the localization of the ore. Ground water probably played an important role in the precipitation of the uranium and sulfides.

\section{CONCLUSIONS}

The Shinarump No. 1 deposit, which is located on the west flank of the Moab anticline, is in the lowermost siltstone beds of the Chinle formation that truncate erosional remnants of Shinarump conglomerate. Uranium deposits in the Seven Mile Canyon area and elsewhere to the south and west are near the margins of Shinarump deposition. There is no evidence to show a definite genetic relationship of the Moab fault to the uranium deposits in the Seven Mile Canyon area.

The ore is relatively unoxidized. Uraninite (pitchblende), a primary mineral, is the most abundant ore mineral. It occurs as small grains disseminated in sandstone and replacing wood structure. Uraninite, which is associated mainly with chalcocite and pyrite, is later formed than most sulfides except chalcocite, which is, in part, later. Chalcocite occurs in vertical fractures that trend east. The ore minerals occur in more poorly sorted parts of siltstone and in stringers of coarse sand in siltstone.

The ore deposit is not in a channel fill but in flat-bedded sedimentary rocks that were deposited on an irregular surface. Guides to ore in the Seven Mile Canyon area inferred from the study of the Shinarump No. 1 deposit are the presence of bleached siltstone, carbonaceous material, and copper sulfides. The deposit lies below thin parts of the limestonepebble conglomerate "marker bed."

The origin of the Shinarump No. 1 deposit is probably hydrothermal. Mineralizing solutions-hydrothermal and, in part, ground water-are thought to have been reducing in character and to have contained important amounts of barium, vanadium, uranium, copper, and sulfur as well as lesser amounts of strontium, chromium, boron, yttrium, lead, and zinc.

\section{LITERATURE CITED}

Buerger, N. W., 1941, The chalcocite problem: Econ. Geology, v. 36 , no. 10, p. 19-44.

Fischer, R. P., 1942, Vanadium deposits of Colorado and Utah: U. S. Geol. Survey Bull. 936-P.

Krumbein, W. C., 1934, Size frequency distribution of sediments: Jour. Sed. Petrology, v. 4, p. 65-77.

Love, J. D. , 1952, Preliminary report on uranium deposits in the Pumpkin Buttes area, Powder River Basin, Wyoming: U. S. Geol. Survey Circ. 176.

McKnight, E. T., 1940, Geology of the area between Green and Colorado Rivers, Grand and San Juan Counties, Utah: U. S. Geol. Survey Bull. 908.

Robertson, F., and Vandeveer, P. L. , 1952, A new diagrammatic scheme for paragenetic relations of the ore minerals: Econ. Geology, v. 47, no. 1, p. 101-105.

Shoemaker, E. M. , 1951, Internal structure of the Sinbad Valley-Fisher Valley salt anticline, Colorado and Utah (abs.): Geol. Soc. America Bull., v. 62, no. 12, part 2.

Stokes, W. I. , and Phoenix, D. A., 1948, Geology of the Egnar-Gypsum Valley area, San Miguel and Montrose Counties, Colorado: U. S. Geol. Survey Oil and Gas Inv., Prelim. Map 93.

Wandke, A. D., 1953, Polishing phenomena in the copper sulfides: Econ. Geology, v. 48, no. 3, p. 225 232.

Waters, A. C., and Granger, H. C. , 1953, Volcanic debris in uraniferous sandstone and its possible bearing on the origin and precipitation of uranium: U. S. Geol. Survey Circ. 224.

Waugh, A. E., 1943, Elements of statistical method: McGraw-Hill Book Co., Inc., p. 99. 


\section{UNPUBLISHED REPORTS}

Droullard, R. F., 1951, Prospective bulldozer operations in the Seven Mile area: U. S. Atomic Energy Commission RMO 689.

Droullard, R. F. , and Jones, E. E. , 1952, Geology of The Seven Mile Canyon uranium deposits, Grand County, Utah: U. S. Atomic Energy Commission RMO 815.

Proctor, P. D., 1949, Geology of the Harrisburg (Silver Reef) mining district, Washington County, Utah: Unpublished doctoral dissertation, Ind. Univ.
Stieff, L. R., and Stern, T. W., 1953, The leaduranium ages of some uraninite specimens from Triassic and Jurassic sedimentary rocks of the Colorado Plateaus: U. S. Geol. Survey Trace Elements Inv. Rept. 322.

Weeks, A. D., 1952, Summary report on mineralogic studies of the Colorado Plateau through April 30, 1952: U. S. Geol. Survey Trace Elements Memo. Rept. 431.

GROUP-NUMBER CLASSIFICATION

\begin{tabular}{|c|c|c|c|c|c|c|c|c|c|}
\hline $\begin{array}{c}\text { Assay } \\
\text { (report in } \\
\text { percent) }\end{array}$ & $\begin{array}{c}\text { Group } \\
\text { no. } 1\end{array}$ & Clas & range & Class mark & $\begin{array}{c}\text { Assay } \\
\text { (report in } \\
\text { percent) }\end{array}$ & $\begin{array}{l}\text { Group } \\
\text { no. }\end{array}$ & Class & 8 range & Class mark \\
\hline $\begin{array}{l}X X .+ \\
X X . \\
X X .- \\
X .+ \\
X . \\
X .- \\
. X+ \\
. X \\
. X-\end{array}$ & $\begin{array}{l}1+ \\
1 \\
1- \\
2+ \\
2 \\
2- \\
3+ \\
3 \\
3-\end{array}$ & $\begin{array}{c}46.4 \\
21.5 \\
10.0 \\
4.6 \\
2.2 \\
1.0 \\
.46 \\
.22 \\
.10\end{array}$ & $\begin{array}{c}-100.0 \\
-\quad 46.3 \\
-21.4 \\
-\quad 9.9 \\
-\quad 4.5 \\
-\quad 2.1 \\
-\quad .9 \\
-\quad .45 \\
-\quad .21\end{array}$ & $\begin{array}{c}68.1 \\
31.6 \\
14.7 \\
6.8 \\
3.2 \\
1.5 \\
.68 \\
.32 \\
.15\end{array}$ & $\begin{array}{l}0.0 \mathrm{X}+ \\
.0 \mathrm{X} \\
.0 \mathrm{X}- \\
.00 \mathrm{X}+ \\
.00 \mathrm{X} \\
.00 \mathrm{X}- \\
.000 \mathrm{X}+ \\
.000 \mathrm{X} \\
.000 \mathrm{X}-\end{array}$ & $\begin{array}{l}4+ \\
4 \\
4- \\
5+ \\
5 \\
5- \\
6+ \\
6 \\
6-\end{array}$ & $\begin{array}{l}0.046 \\
.022 \\
.010 \\
.0046 \\
.0022 \\
.001 \\
.00046 \\
.00022 \\
.0001\end{array}$ & $\begin{array}{cc}- & 0.09 \\
- & .045 \\
- & .021 \\
- & .009 \\
- & .0045 \\
- & .0021 \\
- & .0009 \\
- & .00046 \\
- & .00021\end{array}$ & $\begin{array}{l}0.068 \\
.032 \\
.015 \\
.0068 \\
.0032 \\
.0015 \\
.00068 \\
.00032 \\
.00015\end{array}$ \\
\hline
\end{tabular}

$i^{1}$ Subgroups overlap somewhat, but about 80 percent of cases will be in correct subgroup. 


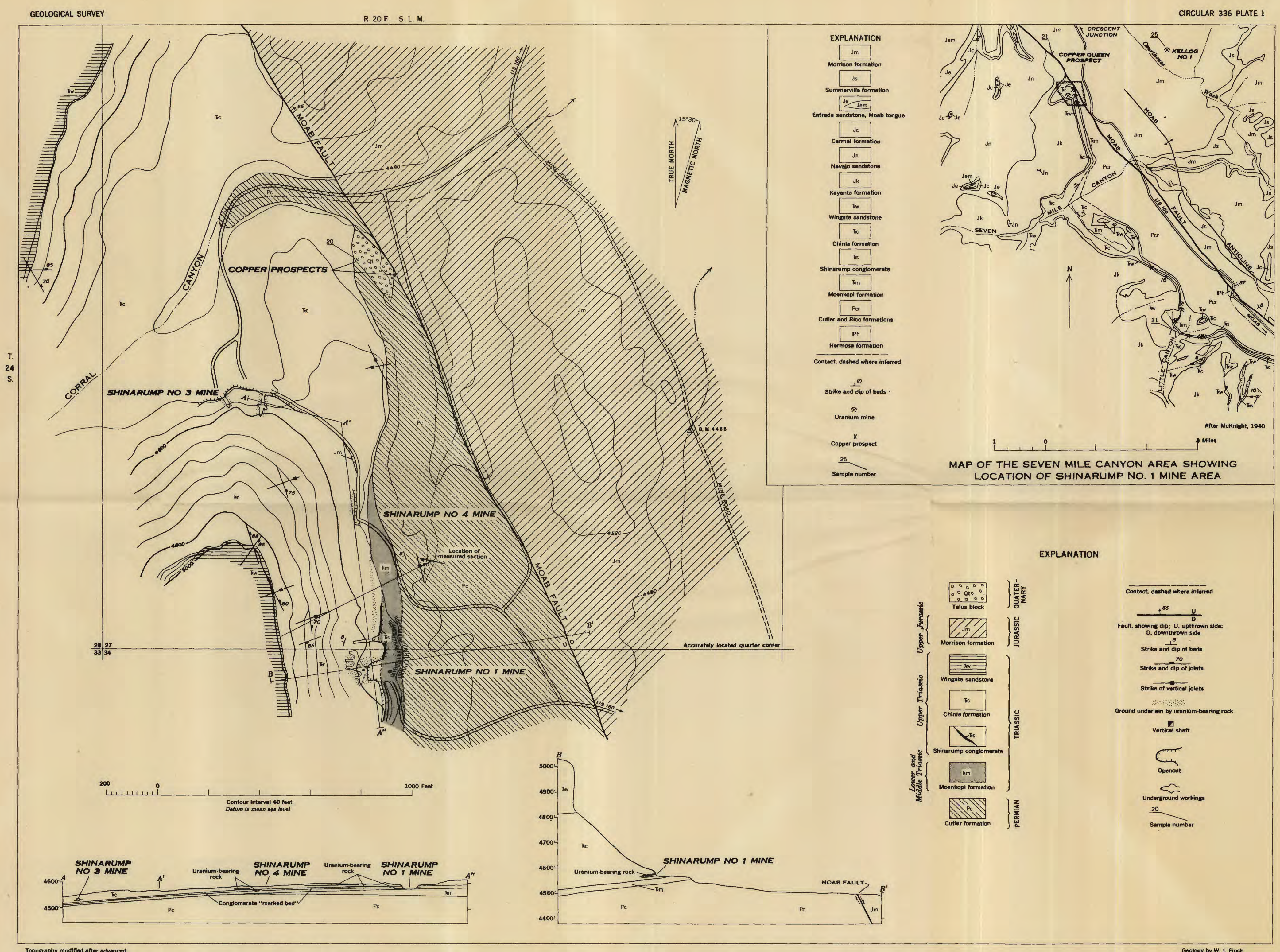

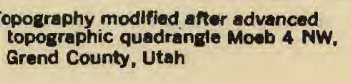




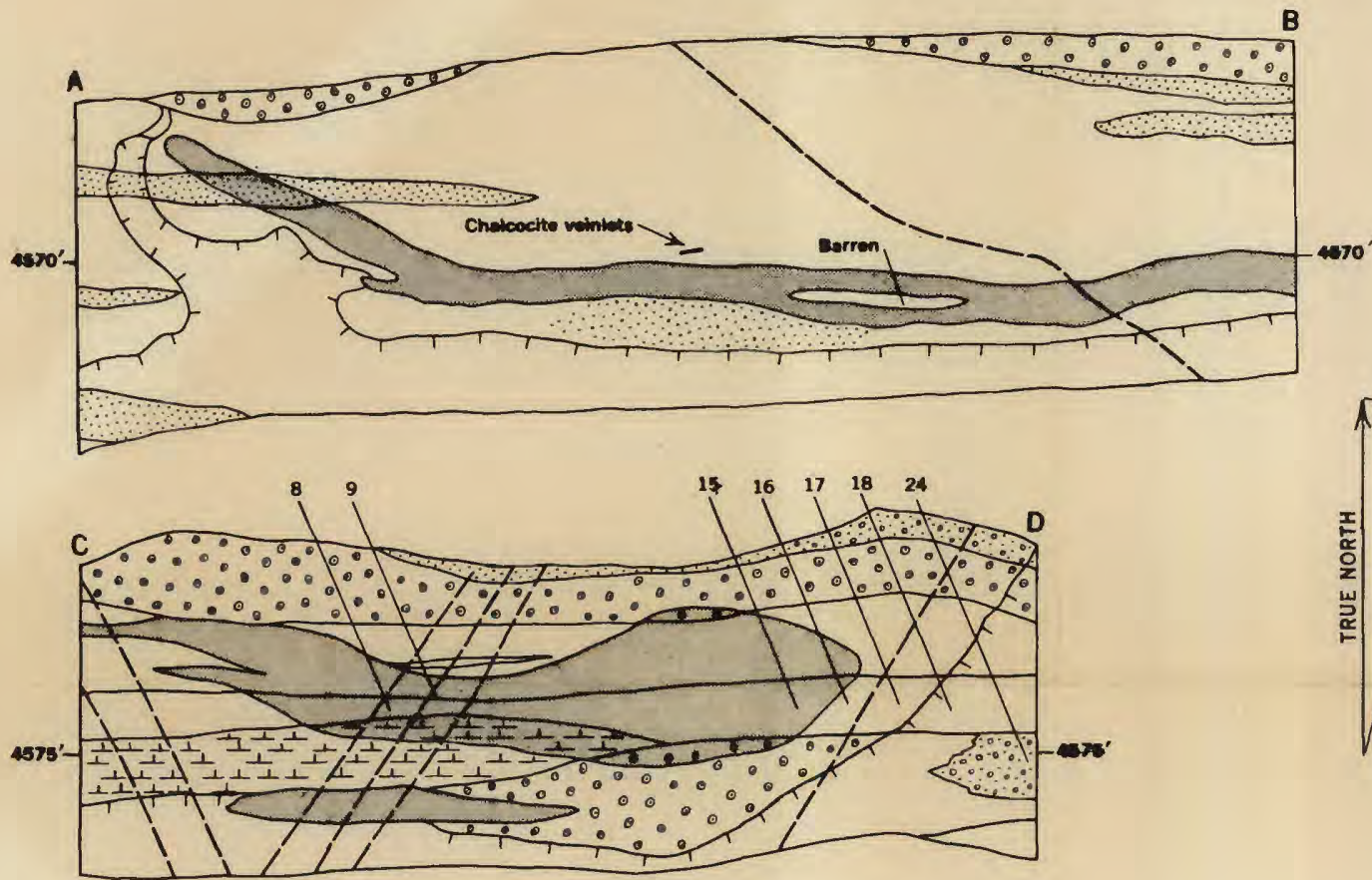

SKETCH SHOWING LOCATION OF MAPS OF MINE WALLS
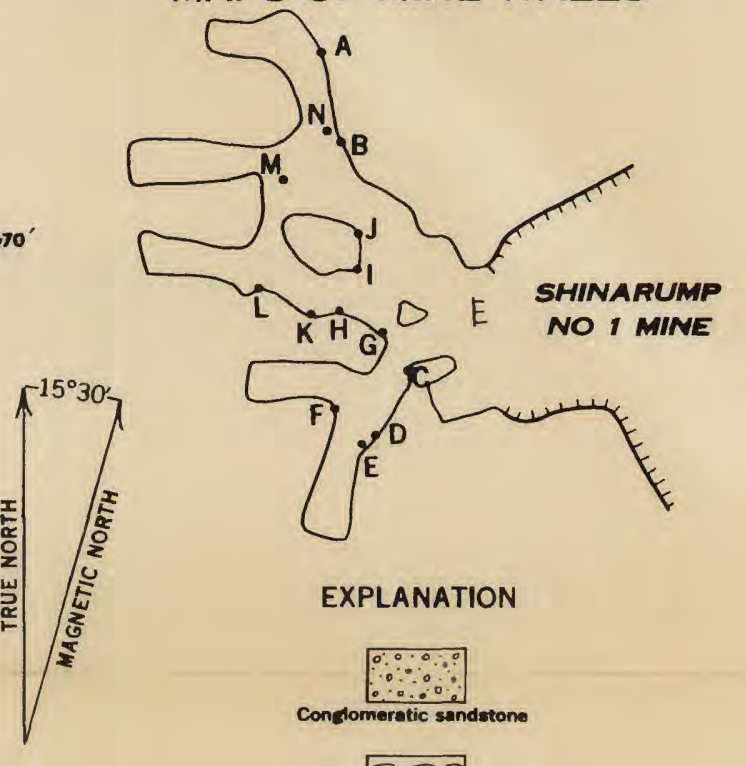

I $\mathrm{KH} D \mathrm{E}$ SHINARUMP P

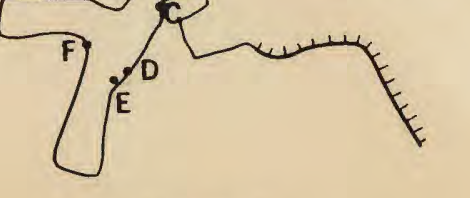

EXPLANATION
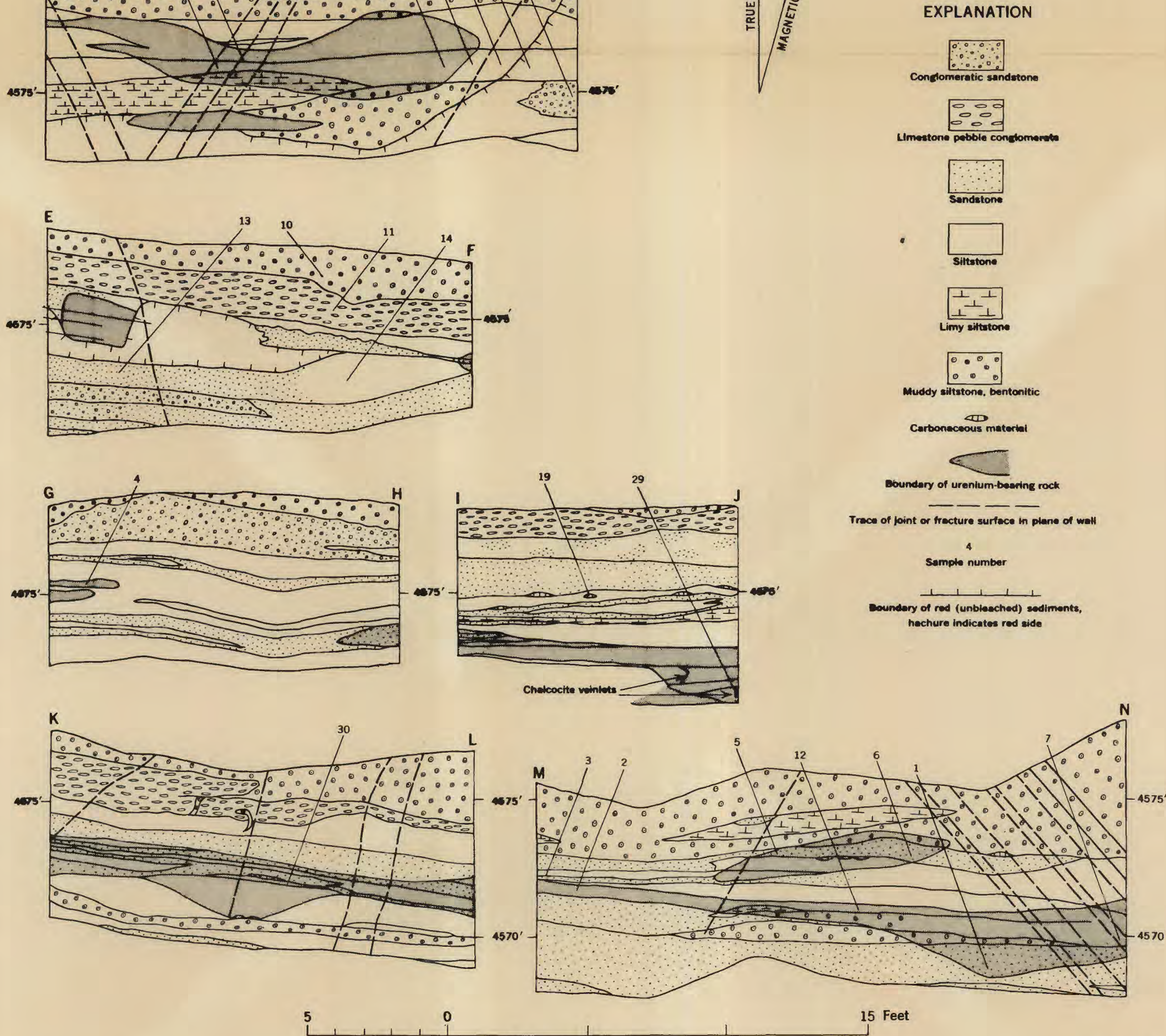

15 Feet

Datum is mean sea level 